\title{
Christian Rößner
}

\section{Mysticism instead of Metaphysics: Marion's Phenomenology of Revelation}

\author{
Mistika namesto metafizike: \\ Marionova fenomenologija razodetja
}

Abstract: In a dense and important text that has recently been published in the Vienna Yearbook for Philosophy, Jean-Luc Marion treats the topic of the complex relationship between phenomenology and theology by inquiring into the philosophical status of mysticism. Whereas the concept and meaning of the mystical commonly have become problematic and suspicious, Christian faith remains based on the "revelation of the mustêrion « (Rom 16, 25). If, in this sense, theology is always already a mystical one, it has to take into account the specific phenomenality of such a manifestation of the mystery the Bible is testifying. By learning from phenomenology to better see what there is being given, theology can help phenomenology to become clear-eyed and to be no longer blinkered by transcendental restrictions of classical apriori-metaphysics.

Key words: mysticism, metaphysics, phenomenology, revelation, God

Povそ̨tek: V zgoščenem in pomembnem članku, ki je nedavno izšel v Wiener Jahrbuch für Philosophie, Jean-Luc Marion obravnava področje kompleksnega odnosa med fenomenologijo in teologijo skozi raziskovanje filozofskega statusa mistike. Medtem ko sta $v$ splošnem pojem in pomen mističnega postala problematična in sumljiva, pa krščanska vera ostaja utemeljena $v$ »razodetju skrivnosti (mysterion)« (Rim 16,25). Če je v tem smislu teologija že vedno mistična, mora upoštevati specifično pojavnost (fenomenalnost) takšnega razodevanja skrivnosti, o kateri pričuje Sveto Pismo. Teologija se od fenomenologije uči bolje videti to, kar se daje, s svoje strani pa fenomenologiji pomaga, da ta razširi svoj pogled in se ne pusti utesnjevati skozi transcendentalne omejitve klasične apriorne metafizike.

Ključne besede: mistika, metafizika, fenomenologija, razodetje, Bog

The classical form of philosophical thinking about God is called metaphysics, so that the concept of metaphysics seems to be coextensive with the concept of philosophical theology. The question is if this classical form is the only one, the 
only possible and hence necessary form of thinking of and about God or the Divine: Do we have to do metaphysics when we think of and about God? ${ }^{1}$ Or can the ^óyos, that for Christian thinking is God himself, be rationally expressed not in the logic of metaphysical theology but in a kind of post- or nonmetaphysical theo-logy which would be no longer dependent upon metaphysics and its philosophical presumptions and pretentions. ${ }^{2}$

To answer that question a precise definition of metaphysics is needed. Understood in the broadest sense of the word, metaphysics is concerned with everything that cannot be taken up in physics. Metaphysics in this widest and vaguest, postor even transphysical sense means precisely the supernatural, what is above, be-

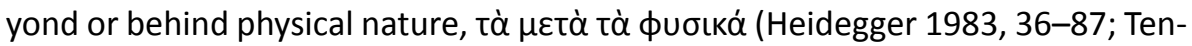
gelyi 2014, 29-45). In this supersensory sense every philosophy that is not identic with natural science and therefore transcending strictly empirical knowledge is metaphysical by itself, by its transnatural nature. And insofar as God is not part of that nature to which we have an experimental access, every thinking of and about the Divine is metaphysical by being an intellectual access to the transcendent.

But beside this generic definition, that is far too unspecified, there is another definition of metaphysics that is much stricter and much more helpful to better understand and interpret the tradition and history of philosophical thinking (Ma-

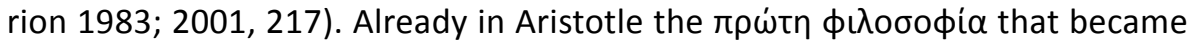
used to be called metaphysics later, is concerned not only with everything that there is and insofar as it is - to ôv ñ ôv - but as well with its principles and the highest causes of being. By inquiring into the most universal aspects and structures of being as such and in general, metaphysics is also thinking an eminent and specified being that is, but par excellence. This indissoluble entanglement of the most universal - metaphysica generalis or ontology - and its highest unity - metaphysica specialis or philosophical theology - can be summed up with Rémi Brague and Jean-François Courtine who have established the notion of a katholouprotologic structure of Aristotelian metaphysics (Brague 1988; 110; 194; 271; 391; 513-515; Courtine 2003, 192-194; see also Tengelyi 2014, 46-83). As a typological feature this interdependency of ontology and theology has been continued by medieval scholasticism and modern rationalism, despite the crisis of metaphysics that is marked by Kantian criticism, calling into question precisely the possibility of metaphysics as rational science. From Kant to Levinas the word, term and notion of metaphysics kept a certain ambiguity (Levinas 1972, 76; 1984, 18-19; Rößner 2018a, 95-97; 130-131), where a kind of pre-critic or old-fashioned metaphysics is criticised by a new form of critical or ethical metaphysics still to come. But it was Heidegger in Identity and Difference who made the attempt to under-

1 For the question: "Does Christianity Need Metaphysics? « see the instructive symposium with Rémi Brague \& Jean-Luc Marion, held November 6, 2014, at the Lumen Christi Institute, University of Chicago (accessible via: https://www.youtube.com/watch?v=Xlan-yjUcxA).

2 Marion 1982, 197: "La théologie ne peut accéder à son statut authentiquement théologique, que si elle ne cesse de se défaire de toute théologie." 
stand the intrinsic affiliation of ontology and theology or "theio-logy ${ }^{3}$ in classical metaphysics, where being always already appears as a cause or ground:

»Because Being appears as ground, beings are what is grounded; the highest being, however, is what accounts in the sense of giving the first cause. When metaphysics thinks of beings with respect to the ground that is common to all beings as such, then it is logic as onto-logic. When metaphysics thinks of beings as such as a whole, that is, with respect to the highest being which accounts for everything, then it is logic as theo-logic." (Heidegger 2002, 70-71)

It is not the least merit of Jean-Luc Marion to have taken up this famous Heideggerian thesis of the onto-theo-logical constitution of metaphysics as a historian of early-modern philosophy: As a hermeneutical principle Marion made Heidegger's insight into the onto-theological character of occidental thought fruitful for a differentiated re-reading of canonical texts and authors as Descartes first of all in whose work Marion analysed the metaphysical prism (Marion 1986a). But insofar as Marion is not only an eminent historian of Cartesian thought, but himself a thinker who is theologically ambitious and inspired by phenomenology, there is still another question that is posed in this connexion by Heidegger: "Someone who has experienced theology in his own roots, both the theology of the Christian faith and that of philosophy, would today rather remain silent about God when he is speaking in the realm of thinking." (Heidegger 2002, 54-55)

The onto-theo-logical character of metaphysics has become highly questionable, for Heidegger as well as for Marion. Whereas the former accuses metaphysics of a misjudgement of the ontological difference, Marion is a disciple of Levinas in accusing onto-theology of another misjudgement: the metaphysical concept of God as causa sui implies a kind of ontological contamination of God. ${ }^{6}$ The problem of onto-theological metaphysics is not to think unreasonably about being, but to think unreasonably, that is: all too reasonably about God. Metaphysics is very well able to establish a supreme principle, a first cause, a last telos, that at the end of the quinque viae of Saint Thomas Aquinas everybody was used to call God. But that by the means of metaphysics we can identify the highest point in which all lines of our thinking consequently converge, does not mean by itself, that this po-

3 Heidegger 1977b, 195: »Theiologie«.

4 Heidegger 2006, 76: „Weil Sein als Grund erscheint, ist das Seiende das Gegründete, das höchste Seiende aber das Begründende im Sinne der ersten Ursache. Denkt die Metaphysik das Seiende im Hinblick auf seinen jedem Seienden als solchem gemeinsamen Grund, dann ist sie Logik als Onto-Logik. Denkt die Metaphysik das Seiende als solches im Ganzen, d. h. im Hinblick auf das höchste, alles begründende Seiende, dann ist sie Logik als Theo-Logik«; see also Gondek and Tengelyi 2011, 353-357.

5 Heidegger 2006, 63: „Wer die Theologie, sowohl diejenige des christlichen Glaubens als auch diejenige der Philosophie, aus gewachsener Herkunft erfahren hat, zieht es heute vor, im Bereich des Denkens von Gott zu schweigen."

6 Levinas 1974, x: "Mais entendre un Dieu non contaminé par l'être, est une possibilité humaine non moins importante et non moins précaire que de tirer l'être de l'oubli où il serait tombé dans la métaphysique et dans lıontothéologie.« see also Rößner $2018 \mathrm{~b}$. 
int that is necessary for our finite reason and made possible by this very reason, is identic with the point where God the Infinite comes to our finite minds. It is the job of metaphysics and onto-theology to identify among all the beings one being that perfectly fits the requirements of a supreme principle or transcendental ideal and therefore could be called God. But that so-called God is logically a God of our own graces! When God is thought by the ways and means of onto-theology, then we think the highest possible vertex that crowns, and by crowning supports, the round arch of reasoning. The Quasi-God of metaphysics is and cannot be unconditioned, because he is subject to the conditions of possibility our reason is stipulating for its highest, highest possible principle. So, if God as God is what is absolutely unconditioned, He cannot be transcendentally conditioned by conditions of possibility. We have to decide: when we want to save the absoluteness of God who is sovereign and does not accept any conditions a conditioned and finite reason is dictating, then God is no more possible. No more possible in the strict sense and definition of metaphysical possibility: A self-revealing God, who comes to mind, but from the outside of the mind, who gives himself, but by himself, is not and cannot be the proven or postulated God of metaphysics. If God is really God and not an idea, ideal or idol of thought, He will always and exactly be the one who, in this well-understood sense, is impossible, that means: impossible for us, for our capacities of thought (Marion 2004; 2006; 2010a; 2010b). Si comprehendis, said Saint Augustine (Sermon 117), whatever you comprehend within the reach of reason, non est Deus (Marion 2008, 392; Grondin 2017, 2). It is not God, because only God Himself can decide and say if His modesty is katabatically or kenotically humble enough to take the seat and place metaphysics has reserved for Him. Metaphysics is the way to think God as possible. But no being here on earth is qualified to define what is possible for God and what it is not. You would have to be God to be able to say that something is impossible for Him. God does not have to respect the conditions of possibility all our possible thinking about God naturally has to respect. God is not necessarily what appears to us to be that what could be called God. So, God is impossible for us because, par definition, nothing is impossible for Him (Lk 1, 37; see Marion 1989 and Marion 2018a, 91). God is greater than the heart (1 Jn $3,20)$, greater than the mind, greater than the largest concept, even that of being (Marion 2018a, 83). That is not to say that God is not, but that when we think about God we strictly think about the Unthinkable.

The necessary failure of the possibilities of onto-theological metaphysics in the face of the auto-manifestation of a self-revealing God marks the starting point where Marion's philosophy of religion commences, beginning with Idol and Distance and God without Being. In the frame of this paper Marion's rich and original thought cannot be expounded, so that it is advisable to give a short presentation of a text that has recently been published in the Vienna Yearbook of Philosophy (Marion 2018a). In this dense and important essay Marion presents mysticism as an alternative to metaphysics. ${ }^{7}$

7 The presentation of this paper paraphrases Marion's argumentation. 
Whereas the concept and meaning of the mystical commonly are considered problematic and suspicious, Christian faith remains based on the "revelation of the mustêrion « (Rom 16, 25). To Christian faith and to Christian theology »it is given to know the mysteries of the kingdom of heaven « (Mt 13,11). But if, in this sense, theology must become the mystical one it always already is, theology has to take into account the specific phenomenality of such a manifestation of the mystery the Bible is testifying (Marion 2018a, 73-74).

For a first determination of the mystical a famous sentence of Wittgenstein's Tractatus (6.522) is to be remembered: "There is indeed the inexpressible. It manifests itself. It is the mystical ${ }^{8}$. Whereas common sense insists that the inexpressible that cannot be put into words cannot become visible either, Wittgenstein points out that there are things that cannot be said, but shown, insofar as they show themselves by, in and from themselves. The problem of the mystical is not that in mystical language we speak without saying anything, but on the contrary that we are not capable to adequately say, express and put into words what nevertheless does not stop to show and manifest itself by, in and from itself. Mystical experience makes no illusions, it has no voice to adequately articulate what it sees show itself. If theology as well has to speak and think about things that are actually unspeakable and unthinkable, because they can be seen for now only darkly as reflections in a mirror (1 Cor 13, 12), theology is inevitable on the border to the mystical and must meditate the phenomenal setting of what manifests itself without being expressible and what appears without being illusion or a mere apparition (Marion 2018a, 74-75).

Now there is a philosophical enterprise whose concern is precisely to reveal the invisible and that is phenomenology. To quote the famous paragraph 7 of $\mathrm{Be}$ ing and Time:

"What is it that phenomenology is to slet us seer? What is it that must be called a sphenomenon in a distinctive sense? What is it that by its very essence is necessarily the theme whenever we exhibit something explicitly? Manifestly, it is something that proximally and for the most part does not show itself at all: it is something that lies hidden, in contrast to that which proximally and for the most part does show itself; but at the same time it is something that belongs to what thus shows itself, and it belongs to it so essentially as to constitute its meaning and its ground." (Heidegger $1962,59)^{9}$

Even if Heidegger probably does not have in mind the problem of the mystical,

8 Wittgenstein 1984, 85: „Es gibt allerdings Unaussprechliches. Dies zeigt sich, es ist das Mystische«.

9 Heidegger 1977a, 35: "Was ist das, was die Phänomenologie ssehen lassen soll? Was ist es, was in einem ausgezeichneten Sinne sPhänomen genannt werden muss? Was ist seinem Wesen nach notwendig Thema einer ausdrücklichen Aufweisung? Offenbar solches, was sich zunächst und zumeist gerade nicht zeigt, was gegenüber dem, was sich zunächst und zumeist zeigt, verborgen ist, aber zugleich etwas ist, was wesenhaft zu dem, was sich zunächst und zumeist zeigt, gehört, so zwar, dass es seinen Sinn und Grund ausmacht.« 
his classic definition of phenomenality shares its paradox: to think what shows itself requires also thinking what does not show itself but is constitutive for everything that shows itself. To gain the visible, phenomenology has to get involved in that invisible which constitutes all visibility. That is why the unspeakable we cannot talk about requires much more than our silence (Marion 2018a, 76).

The consequence of this is not that theology has just to adopt the methods of phenomenological philosophy. On the contrary, Marion quotes Heidegger, for whom "the concept of a Catholic phenomenology is even more absurd than the concept of a Protestant mathematics " (Heidegger 1982, 20; see also Marion $2018 a, 76)^{10}$. When they get into touch with theology, philosophy and phenomenology must stay true to their own rules of which methodological atheism is the most important. For Husserl the transcendental reduction that is practised by phenomenology implies the suspension of all transcendence, of the »horizontal transcendence" of the mundane object as well as of the "vertical transcendence" of a God who is cause and ground of the world and all its objects. God is not part and no possible theme of phenomenology, because God does not appear in the immanence of phenomenal consciousness (Marion 2018a, 78-79).

To skip other difficulties that deal with the deeply problematic character of our access both to the objective world and to the non-representational Other, it seems to have to be stated that we face a multiple blockade that stems from the transcendental character of egoity and does not allow any access precisely to the three main domains theology is concerned with: God as self-revealing Creator, the created world as "book of nature " written by God, and the social world of creatures living a non-solipsistic life (79-80).

Marion's phenomenology does not give up the Husserlian principle of methodological atheism. But there is a change or shift in phenomenology itself that does not result from any stheological turn « (Janicaud 1991) of phenomenology. It is not a kind of ideological takeover of phenomenology by theology, but rather a nearly involuntary and spontaneous self-development of phenomenology which begins to extend over areas of thought that traditionally refer to theology. These advances and attempts of a revised and renewed phenomenology can be summarized with Marion formulating as new principle that there is the more givenness the more there is reduction (Marion 2018a, 82). If we want to take serious the Heideggerian definition of the phenomenon as that which shows itself in, by and from itself, and

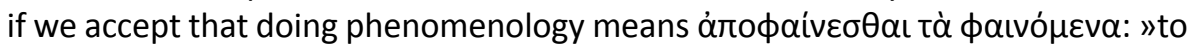
let that which shows itself be seen from itself in the very way in which it shows itself from itself " (Heidegger 1962, 58; also Marion 2018a, 81) ${ }^{11}$, then we have to further investigate in this self of the phenomenon. The self of the phenomenon manifests itself from itself: $k \alpha \theta^{\prime}$ au்tó. But what manifests itself shows itself from

10 Heidegger 1975, 28: „Der Begriff einer katholischen Phänomenologie ist jedoch noch widersinniger als der Begriff einer protestantischen Mathematik«.

11 Heidegger 1977a, 34: „Das, was sich zeigt, so wie es sich von ihm selbst her zeigt, von ihm selbst her sehen lassen«. 
itself only in the exact measure as it gives itself. That something shows itself is only possible if it first gives itself. „Everything that shows itself gives itself, even though not everything that gives itself shows itself« (Marion 2018a, 82).

This Marionian development of phenomenology that prioritizes the donation of givenness implies an understanding of reduction that does no more block methodologically all access to transcendence. When transcendence comes to mind by giving itself, phenomenology has to open or widen the eyes without contradicting the methodological atheism which attached the legitimacy of appearance to the degree of phenomenal givenness.

This first and basic development is accompanied by at least two corollaries (82-83): first, when phenomenological reduction is carried out in accordance to the criteria of givenness, then there is no need to directly link the phenomenological enterprise with ontical or ontological questions (82). Insofar as phenomenology enters the heritage of metaphysics, (the question of) God is cleared and liberated from any onto-theological constrictions. The second consequence consists in the refusal of every identification of phenomenality and objectity. A phenomenon that shows itself only insofar as it gives itself appears much more as an incidental occurrence that is just happening and as a brute fact than as a permanently subsistent object. Instead of the Kantian differentiation of all objects into phaenomena and noumena we have to differentiate between those (poor) phenomena that appear as mere objects, and those (rich or saturated) phenomena that manifest themselves as true and unpredictable events. Such an evenemential transformation of phenomenology entails a new understanding of possibility: the possible is no more that which does not contradict its transcendental conditions and can therefore be anticipated by the constituting synthesis of the subject to which it remains subjected, but rather the opposite, that is: what remains impossible for us insofar as it is an event that is not impossible in itself, but precisely in its evenemential character something absolutely unexpected and surprising (Serban 2016) that can neither be anticipated nor represented in the presence of our mind and consciousness (Marion 2018a, 83).

From these deep Marionian modifications of the original notions of phenomenology two figures emerge: the saturated phenomenon and the successor of the former transcendental subject that Marion calls the adonne and who is both: gifted and giving himself. Without explaining in the frame of this paper these rich and complex figures in further detail (84-88), the point of convergence shall finally be sketched where a phenomenology that is reformed in the sense of the primacy of the given over objects being given, may meet mystical theology.

Theology has always been based on the terms and current concepts of each epoch, but with the aim of better responding and corresponding to what theology is all about. Among these terms and concepts, special consideration traditionally has been given to the term and concept of being in the sense of metaphysics. But if and because Christian theology is and remains centered around the self-revelation of God in Jesus Christ, it must be taken into account that this reve- 
lation is treated in the Bible as an affair of divine self-manifestation, that is: as donation and givenness. In this sense, the biblical character of revelation is radically phenomenal. The terms and concepts theology may use to speak about a revelation that is the event of all events, do not have primarily to respond and correspond to mere objects, but to that over-saturated phenomenon, to that paradox of paradoxes that is absolutely impossible for us (88).

If this phenomenologically evenemential character of the Christ and the modi of his manifestation as the Son of God make necessary such a phenomenological consideration of revelation (92-93), theology could learn from phenomenology to become mystical and close the eyes to see better what there is - not an object but being given. And in return: such a mystical theology could help phenomenology to become clear-eyed and to be no longer blinkered by transcendental restrictions of classical apriori-metaphysics (94).

\section{References}

Aubenque, Pierre. 1962. Le problème de l'être chez Aristote: Essai sur la problématique aristotélicienne. Paris: PUF.

Brague, Rémi. 1988. Aristote et la question du monde: Essai sur le contexte cosmologique et anthropologique de l'ontologie. Paris: PUF.

Courtine, Jean-François. 2003. Les catégories de l'être: Études de philosophie ancienne et médiévale. Paris: PUF.

- - . 2005. Inventio analogiae: Métaphysique et ontothéologie. Paris: Vrin.

Gondek, Hans-Dieter, and László Tengelyi. 2011. Neue Phänomenologie in Frankreich. Berlin: Suhrkamp.

Grondin, Jean. 2017. Augustine's »Si comprehendis, non est Deus": To What Extent is God incomprehensible?. Analecta Hermeneutica 9, 1-13.

Haeffner, Gerd. 1981 [1974]. Heideggers Begriff der Metaphysik. Pullacher philosophische Forschungen 10. München: Johannes Berchmans.

Heidegger, Martin. 1962. Being and Time. Transl. John Macquarrie and Edward Robinson. Oxford: Blackwell.

- - - 1975. Die Grundprobleme der Phänomenologie. Gesamtausgabe 24. Friedrich-Wilhelm von Herrmann, ed. Frankfurt am Main: Klostermann.

- - - 1977a. Sein und Zeit. Gesamtausgabe, I. Friedrich-Wilhelm von Herrmann, ed. Frankfurt am Main: Klostermann.

- - . 1977b. Hegels Begriff der Erfahrung. In: Holzwege, 115-208. Gesamtausgabe 5. Frie-
drich-Wilhelm von Herrmann, ed. Frankfurt am Main: Klostermann.

- - . 1982. The Basic Problems of Phenomenology. Transl. Albert Hofstadter. Bloomington and Indianapolis: Indiana University Press.

- - - 2004 [1983]. Die Grundbegriffe der Metaphysik: Welt-Endlichkeit-Einsamkeit. Gesamtausgabe 29/30. Friedrich-Wilhelm von Herrmann, ed. Frankfurt am Main: Klostermann.

- - - 2002. Identity and Difference. Transl. Joan Stambaugh. Chicago: University of Chicago Press.

- - - 2006. Die onto-theo-logische Verfassung der Metaphysik. In: Identität und Differenz), 51-79. Gesamtausgabe 11. Friedrich-Wilhelm von Herrmann, ed. Frankfurt am Main: Klostermann.

Janicaud, Dominique. 1991. Le tournant théologique de la phénoménologie française. Combas: Éditions de l'Éclat.

Levinas, Emmanuel. 1972. Humanisme et anarchie. In: Humanisme de l'autre homme, 65-82. Montpellier: Fata Morgana.

---. 1974. Autrement qu'être ou au-delà de l'essence. Phaenomenologica 54. La Haye: Nijhoff.

- - - 1984. Transcendance et intelligibilité. Genève: Labor et Fides.

Marion, Jean-Luc. 1977. L'Idole et la Distance: Cinq études. Paris: Bernard Grasset.

- - - 2002 [1982]. Dieu sans l'être. Paris: PUF.

- - . 1983. Du pareil au même, ou: comment Heidegger permet de refaire de l'histoire de la philosophie. In: Martin Heidegger, 177-191. 
Cahiers de I'Herne 45. Michel Haar, ed. Paris: Éditions de l'Herne.

- - . 1986a. Sur le prisme métaphysique de Descartes: Constitution et limites de l'onto-théo-logie dans la pensée cartésienne. Paris: PUF.

- - . 1986b. La fin de la fin de la métaphysique. Laval théologique et philosophique 42:23-33. https://doi.org/10.7202/400214ar

- - - 1989. À Dieu, rien d'impossible. Communio 14:43-58.

- - 1993. Métaphysique et phénoménologie: une relève pour la théologie. Bulletin de littérature ecclésiastique 94:189-206.

- - - 2001. Entretien du 3 décembre 1999. In: Heidegger en France, II: Entretiens, 210-227. Dominique Janicaud, ed. Paris: Albin Michel.

- - - 2004. L'impossible pour l'homme - Dieu. Conférence 18:326-329.

- - - 2006. L'irréductible. Critique 704/705:79-91.

- - . 2008. Au lieu de soi. L'approche de Saint Augustin. Paris: PUF.

- - - 2010a. L'impossibilité de l'impossible: Dieu. Archivio di Filosofia 78:21-36.

- - - 2010b. L'impossible ou le propre de Dieu. In: Certitudes négatives, 87-138. Paris: Bernard Grasset.

- - - 2011. Remarques sur l'utilité en théologie de la phénoménologie. Archivio di Filosofia 79:1121.

- - - 2012a. La question de l'inconditionné. In: Dieu en tant que Dieu, 239-261. Philippe Capelle-Dumont, ed. Paris: Cerf.

- - - 2012b. Qu'attend la théologie de la phénoménologie?. In: »Nous avons vu sa gloire«: Pour une phénoménologie du Credo, 13-31. Nicolas Bauquet, Xavier d'Arodes de Peyriague, and Paul Gilbert, eds. Bruxelles: Lessius.

- - - 2013. Du fondement de la distinction entre théologie et philosophie. In: Praedica Verbum: Scritti in onore del Cardinal Gianfranco Ravasi nel suo $70^{\circ}$ compleanno, 175-187. Marco Garzonio, ed. Milano: Ambrosianeum.

- - - 2015. Doubler la métaphysique. In: Métaphysique et christianisme, 167-186. Paris: PUF.

- - - 2016. Givenness \& Revelation. Transl. Stephen E. Lewis. Oxford: Oxford University Press.

- - . 2018a. Mystik - oder: Was die Theologie sehen lassen kann. Transl. Christian Rößner. In: Das Heilige: Eine grundlegende Kategorie der Religionsphilosophie, 73-94. Wiener Jahrbuch für Philosophie 49. Michael Hofer and Rudolf Langthaler, eds. Wien: new academic press.

- - - 2018b. Das Erscheinen des Unsichtbaren: Fragen zur Phänomenalität der Offenbarung. Transl. Alwin Letzkus. Freiburg: Herder.
Rößner, Christian. 2018a. Der »Grenzgott der Moral«: Eine phänomenologische Relektüre von Immanuel Kants praktischer Metaphysik im Ausgang von Emmanuel Levinas. Phänomenologie: Kontexte 26. Freiburg: Karl Alber.

- - - 2018b. Gott ohne Sein? Emmanuel Levinas und Jean-Luc Marion. In: Das Heilige: Eine grundlegende Kategorie der Religionsphilosophie, 97-123. Wiener Jahrbuch für Philosophie 49. Michael Hofer and Rudolf Langthaler, eds. Wien: new academic press.

Serban, Claudia. 2016. Surprise et saturation. Alter 24:69-80. https://doi.org/10.4000/alter.424

Tengelyi, László. 2014. Welt und Unendlichkeit: Zum Problem phänomenologischer Metaphysik. Freiburg: Karl Alber.

Winter, Stefan. 1993. Heideggers Bestimmung der Metaphysik. Symposion 96. Freiburg: Karl Alber.

Wittgenstein, Ludwig. 1984. Tractatus logico-philosophicus. Werkausgabe 1. Frankfurt am Main: Suhrkamp. 